\title{
Situating Anthropology in Bangladesh: Transformations and Trajectories in the Anthropology Tradition
}

\author{
Saifur Rashid ${ }^{1 *}$, Hasan A. Shafie ${ }^{1}$ \\ ${ }^{1}$ Department of Anthropology, University of Dhaka, Bangladesh \\ *Corresponding Author: saifur_rashid66@hotmail.com \\ Citation: Rashid, S. and Shafie, H.A. (2017) Situating Anthropology in Bangladesh: Transformations and \\ Trajectories in the Anthropology Tradition, European Journal of Sociology and Anthropology, 2(1), 03. \\ https://doi.org/10.20897/ejsa.201703
}

Published: August 31, 2017

\begin{abstract}
The Anthropology tradition, and the associated 'production of knowledge in the academic field, is relatively of recent origin in Bangladesh. The article intends to shed light on anthropology as becoming a separate field of knowledge through exploring the historical trajectories and significant transformations in Bangladesh. Anthropology remains a changing discipline in this country and as such, it continues to remain endlessly fascinating. The anthropological enterprises, in understanding social realities of this region, have begun in early fifties of the twentieth century. The early anthropological enterprises by individual scholars have paved the pioneering institutional pathways of engagement with anthropology in late seventies. The present article extensively reviewed these major anthropological enterprises in Bangladesh from a historical perspective, identifying changing subject matters and trends within this academic tradition, shifting patterns of interests, and depicting areas of activities and concerns of anthropology in this region. Drawing on the empirically grounded works, in Bangladesh and neighboring regions, the paper would allow the readers to assess the overall attainments and limitations of contemporary anthropology in Bangladesh. The article would critically analyze some of the existing dilemmas, contested issues, and contemporary theoretical and practical challenges of applying anthropological perspectives for accelerating development in Bangladesh.
\end{abstract}

Keywords: Bangladesh, anthropology, development, engagement and challenges

\section{INTRODUCTION}

The article aims at surveying the history of anthropology in Bangladesh and would allow the readers to assess the overall attainments and directions of contemporary anthropology in the country. The discussion would shed light on present research interests, and areas of activities and concerns of this academic tradition particularly of this region. The anthropology tradition, and the associated 'production of knowledge' in this academic field, is relatively of recent origin in Bangladesh. We would try to develop an historical account on anthropology as becoming a separate field of knowledge and some of the contemporary practical challenges of applying or involving anthropological perspectives in devising successful strategies to bring about equitable development in the context of Bangladesh. This article aims to provide and an excellent opening for future reference on anthropological subjects and the progress of this discipline in Bangladesh.

Anthropology is relatively a new academic discipline in Bangladesh. In last forty-five years, since the independence of the country, both foreign and local anthropologists have extensively conducted ethnographic fieldwork in Bangladesh and developed some discourses about the dynamics of changing society of Bangladesh with their own specificity, which has had also a profound impact on the discipline as a whole. At present, there are 07 public universities, which have both graduate and postgraduate program in anthropology. Non-degree 
anthropology courses are also taught at some private universities. Every year, about 500 students get enrolled in anthropology program in different public and private universities. The present departments of anthropology at the universities differs in their own focus, curriculum and syllabus planning, and setting priorities and concerns, yet they constitute significant premises for generating, modifying, reproducing, retaining and articulating anthropology as a system of knowledge, embracing social/cultural anthropology as the major field of orientation and of interest (Z. Islam \& Shafie, 2006)

\section{ANTHROPOLOGY IN BANGLADSH: PHASES OF DEVELOPMENT}

Anthropology started as an extension of natural history and gradually engaged in the study of so-called primitive man, of other cultures and societies. Anthropological enterprises are intended to explaining human behavior and the context in which the behavior embedded and is acted out. Although the institutional development of anthropology in Bangladesh is very recent, yet the ancient or early writings by travelers, missionaries and colonial administrators have presented anthropological materials on this region. These writings on the cultural or social history of these region contains anthropological essence, which, in terms of Eriksen and Nielsen, can be defined as protoanthropology or near-anthropological writings (Eriksen \& Nielsen, 2001). Of these proto-anthropological works, the earliest descriptions are mostly travelogues followed by missionary descriptions and colonial administrative records. We, however, can recognize the three developmental phases of anthropology in Bangladesh.

\section{The Formative Phase and Earlier Works}

The sources of our knowledge on social life in Bengal during ancient and medieval period are very scanty, except a few literary sources(Rahim, 1963). Description on social and cultural fabric during precolonial period of this region mainly came from the travelers and missionaries. Some of the significant writings on Indian subcontinent including Bengal are: Battuta (2004), Bernier (1916), Bouchon\&Thomaz (1988 original in 1521), Du Jarric (1615), Huan\&Ch'eng-Chün (1970 original in 1544), Legge (1886), Manrique (1653trans. by Luard, \&Hosten in 1926), Phillips (1885), Van der Heiden (1675) and Xuanzang (trans. by Beal in 1958). The subject matter of these writings are on various themes including village life, settlement pattern, geography, navigation, religion, trade and commerce, culture, local institutions and administration, and so on. The authors of these sources were mostly foreign-born travelers, sailors, traders or missionaries who had been trying to understand other cultures.

During colonial period, a significant number of studies have been conducted to explore the life of people living in this subcontinent. These studies were mainly driven by the colonial interest of conquest and bring people under administrative control. The studies mainly focused on several themes, for instances, language and linguistic features of different groups, caste system and social stratification, racial characteristics of the local people, social features of different ethnic/ tribal groups and so on. Apart from these, there were some travelogues and missionary reports contributed to the production of knowledge on the social life of this subcontinent during colonial period. Table 1 provides an overview of the significant sources of information on the life of people under colonial administration.

The production of anthropological knowledge on this region (Bangladesh) begun during post-colonial era particularly around the middle of twentieth century. The Department of Sociology was founded in 1957 at the University of Dhaka which initially served as a forum for organizing ethnographic and ethnological studies in Bangladesh. During 50s, a number of anthropologists from different countries also did explorations in the Chittagong Hill Tracts (CHT) of Bangladesh. The first initiative came from UNESCO by sending Claude LeviStrauss, the eminent French social anthropologist, to explore the possibilities of the development of social sciences in Bangladesh (A. N. Karim, 1974). Professor Levy-Strauss met government officials as well as university teachers and emphasized that together with the planning for the development of natural resources, the administration should not be oblivious to the development of human resources, without which all grandiose schemes for economic development might be frustrated (ibid). He had conducted short fieldwork on the deciduous forest people of Chittagong Hill Tracts in the eastern part of Bangladesh and was very much amazed seeing the rich storage of cultural diversities of the ethnic communities of Bangladesh. His fieldwork later paved the way for many other national and foreign anthropologists to do rigorous fieldwork among the ethnic, rural and peasant communities of Bangladesh. Karim mentioned the significance of the Professor Levy-Strauss's visit to Bangladesh and CHTs (A. N. Karim, 1974):

\footnotetext{
He [Professor Levy-Strauss] was so much impressed by the pristine and untarnished primeval condition of the tribesmen, such as, the Mugs, the Murangs that at a gathering of intellectuals at Dacca, he in his enthusiasm exclaimed: "Bangladesh is a veritable place for social anthropologists". On his return to Paris, he continued to take active interest in the development of social sciences in Bangladesh, and began to send a series of scholars for the study of the tribal life as well as help develop the teaching and researches in the social sciences. In 1957, with UNESCO's help and assistance, the University of Dacca brought into existence a separate Department
} 
Table 1. Formative works shaping the emergence of Anthropology in Bangladesh.

\begin{tabular}{lll}
\hline \multirow{2}{*}{ Timeline } & \multicolumn{2}{c}{ Formative Anthropological Works } \\
\cline { 2 - 3 } & Influential Works on Indian Subcontinent & Formative Works on Bangladesh Region \\
\hline Pre-Colonial Era & Travelogues and writings about India: (Battuta, & Travelogue (Bernier, 1916; Bouchon \& \\
(Before 1757) & 2004; Legge, 1886; Manrique, Trans. by Luard, \& & Thomaz, 1988 [Original in 1521]; Du Jarric, \\
& Hosten, 1926 [Original in 1653]; Phillips, 1885; & 1615; Huan \& Ch'eng-Chün, 1970 [Original in \\
& Xuanzang \& Beal (Trans.), 1958). & 1544]; Manrique et al., 1926 [Original in \\
& & 1653]; van der Heiden, 1675). \\
\hline
\end{tabular}

Colonial era

$(1757-1947)$

\section{Language and Linguistic Studies (D. Bernot, 1958;} Buchanan, 1799; Campbell, 1874; Konow, 1903; Pinnow et al., 1942; Sebeok, 1942; Shafer, 1955; SmithForbes, 1881; von Hevesy, 1930; Whitney, 1875). Caste and Racial Studies(Bose, 1967; Guha, 1936; Havell, 1918; J. H. Hutton, 1946; Majumdar, 1947; Morris, 1888; Sherring, 1879).

Ethnic/ Tribal Studies (Brown, 1922; Buchanan, 1799; Dalton, 1872; G. A. Grierson, 1906; T. C. Hodson, 1922; Hughes, 1881; W. W. Hunter, Kisch, Mackie, O’Donnell, \& Risley, 1877; R. S. Hutchinson, 1909; J. Hutton, 1921; J. H. Hutton, 1946; Lewin, 1869, 1870; Mills, 1931b; O’Malley, 1908; Phayre, 1841; Pogson, 1831; Risley, 1892, 1908; Roy, 1912, 1915; S. C. Roy, 1916; Roy, 1928; S. N. Roy, 1916; Sen, 1931; StJohn, 1873).

Travelogue, Administrative and Other Studies (Aurousseau, 1920; Baden-Powell, 1896; Bose, 1929; Buchanan, 1807; Gait, 1906; Hoernle \& Stark, 1906; W. W. Hunter, 1886; S. W. Jones, 1784; W. Jones, 1801; Lewin, 1885).

\section{Post-Colonial Language and Linguistic Studies (D. Bernot, 1958;}

Era

(Independence

of India and Shafer, 1955).

Pakistan in 1947) 1957, 1970; Beteille, 1965; S. Dube, 1963; S. C. Dube, 1958, 1964; Dumont, 1969; Dumont \& Pocock, 1957; Elwin, 1947, 1964; Ghurye, 1957, 1969; Gough, 1955; Hasan, 1967; J. H. Hutton, 1961; Leach, 1960; Lewis, 1958; Majumdar, 1937, 1958, 1961; Marriott \& Beals, 1955; Mayer, 1956, 1960; Opler \& Singh, 1952; Sarkar, 1954; Sivertsen, 1963; M. Srinivas \& Shah, 1960; M. N. Srinivas, 1952, 1960a, 1960b; Thorner, 1966; Vidyarthi, 1969; Wiser, 1936).

Ethnic/ Tribal Studies (Datta-Majumder, 1956; Majumdar, 1961).

\section{Language and Linguistic Studies}

(Buchanan, 1799; Campbell, 1874; G. Grierson, 1904; G. A. Grierson, 1906, 1968; Konow, 1903; Pinnow et al., 1942; Sebeok, 1942; von Hevesy, 1930).

Ethnic/ Tribal Studies (Dalton, 1872; T. Hodson, 1921; W. Hunter, 1876; W. W. Hunter et al., 1877; R. H. S. Hutchinson, 1906; R. S. Hutchinson, 1909; Lewin, 1870; Mackenzie, 1884; Mills, 1931b; O’Malley, 1908; Pogson, 1831; Risley, 1892; Roy, 1912; Sen, 1931; St-John, 1873).

Travelogue, Administrative and Other

Studies (Ahmad, 1956; Bontekoe, 1929; Hosten, 1925; Jack, 1915; Mills, 1931a; Nathan, 1936; Prance, 1916).
Village Studies (Ahmad, 1956; Ahmed, 1969; Beech, Bertocci, \& Corwin, 1966; Greenhill \& HILL, 1957; Hara, 1967; Husain, 1962; A. Islam, 1969; Lindenbaum, 1968; McCarthy, 1967; Mukherjee, 1948; Qadir, 1960;

Rashiduzzaman, 1968; Zaidi, 1970).

Ethnic/ Tribal Studies (L. Bernot, 1960; Bessaignet, 1958; Furer-Haimendorf, 1958; R. H. S. Hutchinson, 1906; R. S. Hutchinson, 1909; Kauffmann, 1962; F. Khan \& Choudhuri, 1965; F. K. Khan \& Khisha, 1970; Levi-Strauss, 1951; Lévi-Strauss, 1952; Löffler, 1964, 1968; Sopher, 1964).

\section{of Sociology. Thus, the introduction of sociology marked another major step in the development of social sciences in Bangladesh.}

Following Levi-Strauss, PiereeBassaignet, a sociologist from France and David Sopher (1963, 1964), a renowned South-Asian cultural geographer from the United States also conducted studies on the ethnic/ tribal communities of Chittagong Hill Tracts. Professor Pieree Bassaignet was appointed as the first Head of the Department of Sociology at the University of Dhaka. David Sopher wrote a number of articles based on his anthropological exploration in Chittagong. A few of those articles were published in the Annals of the Association of the American Geography and the Geographical Review. Lucien Bernot (1957) another social anthropologist wrote articles on Chittagong Hill Tribes. During the 1950s and 1960s, many of the sociologists worked on various anthropological issues mostly focusing on rural politics, power structure, social stratification, peasant societies and the ethnic communities. Nazmul Karim, a faculty member of the Sociology Department during that time, did his Ph.D. under the supervision of T. B. Bottomore at the University of London basing on anthropological and ethnohistoric data collected from a village of Bangladesh. Karim's comparative study on Muslim stratification of India, Pakistan and Bangladesh is one of pioneering study in the area of social anthropology. During that period, "in Dacca University, anthropology has been proposed to be taught as a separate discipline under the auspices of the 
Table 2. Founding works guiding the establishment of Anthropology discipline in Bangladesh

\begin{tabular}{|c|c|c|c|}
\hline \multicolumn{2}{|c|}{ Focus of Interest } & \multirow{2}{*}{ Example of Works } & \multirow{2}{*}{$\begin{array}{l}\text { Dominant } \\
\text { Paradigms }\end{array}$} \\
\hline Themes & Issues & & \\
\hline $\begin{array}{l}\text { Village } \\
\text { Studies }\end{array}$ & $\begin{array}{l}\text { Peasant Class } \\
\text { Differentiation; Mode of } \\
\text { Production; Agrarian } \\
\text { Structure and social } \\
\text { formation; Rural Power } \\
\text { Structure and } \\
\text { Leadership; Rural } \\
\text { Development; Gender } \\
\text { and Reproductive } \\
\text { Health. }\end{array}$ & $\begin{array}{l}\text { (Adnan \& Rahman, 1978; Ali, 1975; Arefeen, 1986; Arens \& } \\
\text { Van Beurden, 1980; Aziz, 1979; Aziz \& Maloney, 1985; } \\
\text { Bertocci, 1972, 1977, 1984; Blair, 1974; Blanchet, 1984; A. } \\
\text { Chowdhury, 1978; Ellickson, 1972; Haq, 1973; Hartmann \& } \\
\text { Boyce, 1983; Herbon, 1985; A. Islam, 1973; A. A. Islam, 1974; } \\
\text { Jahangir, 1979; Jannuzi, Jannuzi, \& Peach, 1980; Jansen, 1987; } \\
\text { A. Karim, 1984; A. K. N. Karim, 1976; A. Z. Karim, 1990; F. } \\
\text { R. Khan, 1979; Martius-von Harder, 1981; Miller, 1984; } \\
\text { Rahman, 1981; Sarker, 1976; Thorp, 1978; Van Schendel, 1981; } \\
\text { Westergaard, 1983; Wood, 1976; Zaman, 1982) }\end{array}$ & $\begin{array}{l}\text { Marxism, } \\
\text { Modernization } \\
\text { theory, } \\
\text { dependency and } \\
\text { world system } \\
\text { theories }\end{array}$ \\
\hline $\begin{array}{l}\text { Ethnic/ } \\
\text { Tribal } \\
\text { Studies }\end{array}$ & Descriptive Ethnography & $\begin{array}{l}\text { (Chakroborty, 1977; R. I. Chowdhury, Mia, Hossain, } \\
\text { Choudhury, \& Golamquddus, 1979; S. Islam \& Ray, 1984; S. } \\
\text { N. Islam, 1981; Mey, 1978; Qureshi, 1984; Sattar, 1971, 1975; } \\
\text { A. Serajuddin, 1971; A. M. Serajuddin, 1984) }\end{array}$ & $\begin{array}{l}\text { Cultural } \\
\text { evolution, } \\
\text { structural } \\
\text { functionalism }\end{array}$ \\
\hline
\end{tabular}

Department of Sociology, and it is expected that all other universities will take similar steps in the near future" (Karim 1974: 3).

\section{Foundation Phase of Anthropology during 70's and 80's}

The development of higher education receives impetus from state policies and plans. Bangladesh became independent in 1971 which brought into existence a set of different political ideologies and commitments with the spirit of secularism. The necessity of anthropology within institutional framework was gradually recognized in different universities which was expressed in the writings of Professor Karim, "Chittagong University has by now separate departments for sociology, political science and economics, and the creation of a department of anthropology and another department of public administration is under contemplation. Jahangirnagar University which started functioning just a few years ago at Savar, near Dacca, has organized the department of economics and plans to have departments of political science, sociology and anthropology in the near future" (Karim 1974: 3). But the said necessity of anthropology as a separate discipline was not materialized until the middle of 1980s.

The advancement of anthropology in Bangladesh continued with the efforts of a few individual scholars having academic affiliations to universities and institutions abroad during sixties and seventies. These studies were mainly village studies conducted by anthropologists, sociologists and scholars of allied disciplines of both home and abroad, following anthropological research tradition of doing intensive fieldwork. These scholarly works laid foundation of anthropological studies on various issues including rural social structure, power structure, social stratification, land tenure systems, agrarian structure, kinship systems and others (see Table 2).

Besides the department of sociology at different universities, the Institute of Bangladesh Studies (IBS) at the University of Rajshahi played another significant role in the development of anthropology in Bangladesh. The institute was established in 1974 and since then, it has been carrying out a lot of anthropological research on various aspects of rural societies. As a post-graduate research institute, IBS has been regarded as one of the most prestigious institutions in the country, which has attracted many foreign anthropologists to work in Bangladesh. For example, Jean Ellickson of the Western Illinois University of the USA (1974), Peter Bertocci an anthropologist from the Oakland University of the USA worked with the institute in 1974 and 1975 respectively and supervised a number of postgraduate research students. Joana Kirkpatrick was another anthropologist from Bennington College of the USA joined the institute in 1976 and stayed there for a little more than a year. After that, a Bangladesh-born American anthropologist named A.K.M. Aminul Islam from the Wright State University joined the institute in 1978, while followed by him, another American anthropologist Raymond Lee Owens arrived at the institute in 1979. Clarence C. Maloney, an anthropologist and linguist from the United States also worked with the IBS from 1979 to 1982. Mr. Jane Paul Emmert, an anthropologist from the University of Hawaii of the USA also worked with the IBS. Thus, the Institute of Bangladesh Studies played a significant role in the development of anthropology in the mid-1970s and 1980s. It is important to note that the IBS has been offering Anthropology as a required course for its M. Phil. and Ph.D. students. It is perhaps the only institute in the country at the postgraduate level which promotes anthropology among its students. It also provides its students with financial assistance and a work environment for carrying out anthropological research relating to topics on Bangladesh society and culture. 


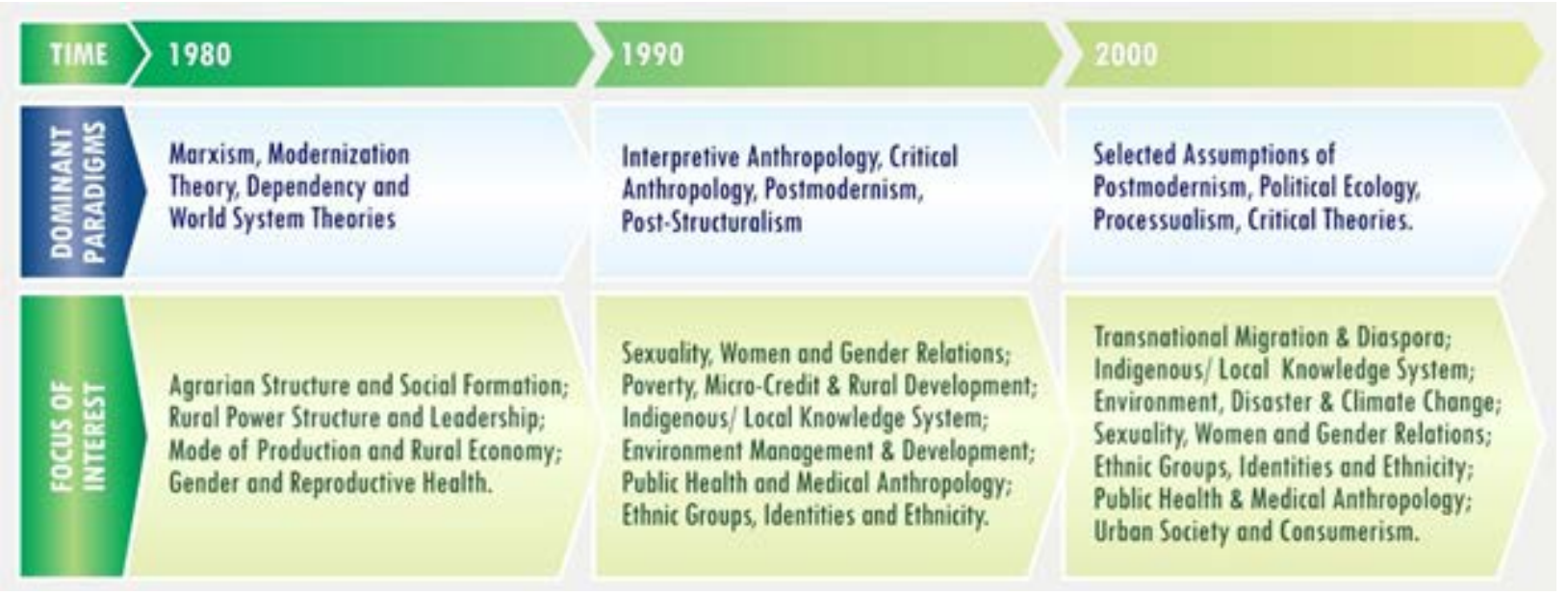

Figure 1. The transformation of research interests in Anthropology of Bangladesh from 1980 to 2010

\section{The Establishment Phase of Anthropology as a Separate Discipline}

Anthropology as a separate discipline was first introduced at the Jahangir Nagar University in 1985/86. After that, a number of other public universities started Anthropology Programs (both Honors and Masters) during the 1990s and early 2000s. They include the University of Dhaka (1992), University of Chittagong (1996), Shahjalal University of Science and Technology (1995), University of Rajshahi (1998/99), University of Comilla (2009) and the Jagannath University (2007/8). During the same period, a number of private universities also came forward to offer anthropology courses within their Anthropology/ and Sociology or Social Science programs. Independent University of Bangladesh, North South University, East West University, BRAC University, Green University, Dhaka International University, Northern University, University of Asia Pacific, ASA University, University of Liberal Arts Bangladesh and few others have now anthropology programs either as separate department or anthropology as allied courses of other departments. In the last thirty years, anthropology has become a demandable subject within the faculty of Social sciences of different universities; and so, a large number of our country's brightest students are now attracted to the graduate and postgraduate programs of anthropology.

At this juncture, it must be noted that the areas of research interest of anthropologists and sociologists changed over different periods of time in Bangladesh. For example, during the period of the 1950s and 1960s, sociologists and anthropologists were mainly interested in doing research on tribal communities and the caste systems in rural Bangladesh, while during the period of the 1960s to 1980s the focus of interest shifted to the study of rural societies. The former periods were mainly influenced and characterized by the 'utilitarian' and 'interventionist' approaches embedded in colonial anthropology. But that does not mean that anthropologists or sociologists of these periods were preoccupied with naïve mimicry of the colonial tradition. Their works belong to these periods also bore the post-colonial ideology and sentiments marked by the intention to nativize anthropology which eventually weakened the colonial hegemony over the discipline. These periods along with the 1960s witnessed the uprise of cultural movements in the then East Pakistan (now Bangladesh) emanated from the struggle against the oppression of the Pakistani rulers which eventually led to the independence of Bangladesh in 1971. Works done by anthropologists or sociologists during these periods had a soul searching attempt in order to find out the cultural diversity history of the people. This trend continued till 1980s where anthropologists and sociologists of the newly independent country mainly focused on the agrarian dynamics of the rural society. The anti-imperialist political motivation among the native scholars at this time paved the way for studying rural societies from various genres of left-inclined theoretical paradigms. But due to the frustration with the oversimplification of the structuralist approaches, during the 90s anthropology and sociology, two separate traditions now, took an interpretive and critical turn influenced by the post-modernist and post-strcturalist knowledge tradition. This tradition still dominates the anthropological and sociological researches in Bangladesh accommodating issues like identity, gender, environment and ecology, development, migration and diaspora, transnationalism etc.

The shifts in the research interests among the anthropologists of Bangladesh have clear reflection in the research works done by the postgraduate students in different anthropology departments of the country. Even though anthropology is now being taught in six public universities, we could collect data of the students' work from four universities covering a time frame from 2005 to 2015. But it must be remembered that not all four departments shared common interests, rather they have heterogeneous research priorities as shown in Figure 2. It shows that while the students of Janhangir Nagar University had a high concentration on gender and sexuality related issues, ethnography and village studies have been dominant among the students of Dhaka University and Shahjalal University. And the students of Chittagong University have shown highest interest in issues pertaining 


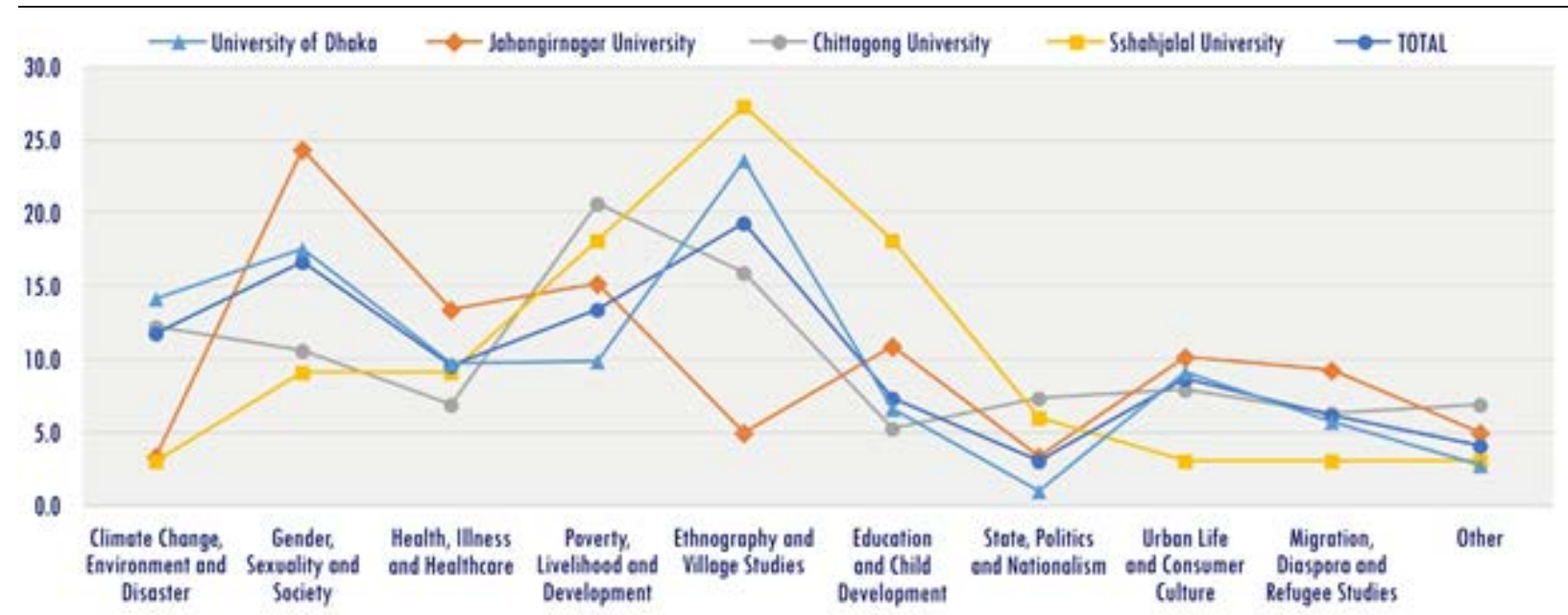

Figure 2. Focus of interest at postgraduate level research works in Anthropology from 2005 to 2015

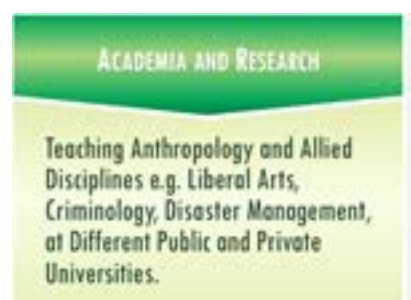

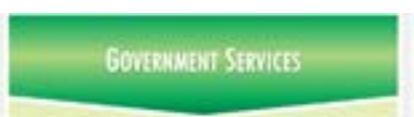

Cedre Services: Administrotive Services of Ministries; Internal Security; Non-Codre Servites eg. Govt. Banks; Manicipol Authority, Dept. of Educotion, Immigratios etc.

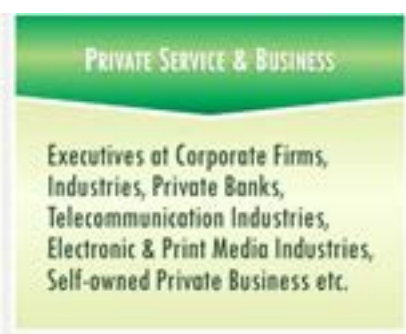

Figure 3. Major employment for Anthropology graduates in Bangladesh

to poverty, livelihood and development. Apart from the major research areas graphed above, students of all the universities have also conducted research on issues like gerontology, film and media, folklore, historical construction, tourism industry, ship-breaking industry etc. which have been grouped under a separate category titled as 'other'.

\section{SECTORS OF EMPLOYMENT OF ANTHROPOLOGY GRADUATES}

In Bangladesh, like in other countries of the world, students who are graduating from various departments of anthropology are being mostly employed in national and international development and research organizations. For many organizations, anthropology graduates are the top choice as most of the anthropology students can easily engage with various community and social development activities. Special training on doing fieldworks among different communities, societies and cultures helps anthropology students to get involve in various research, development and action programs. Moreover, the multi-layered and critical understanding of the anthropology graduates over the complex social and cultural trajectories works as motivating factors for the development organizations to accommodate anthropology graduates. Now there are hundreds of local and international nongovernment organizations in Bangladesh, where anthropology graduates can easily get jobs with good salary packages. Opportunities for higher education in different foreign universities are also increasing.

Beside different national and international development organizations, the Government is also giving due emphasis on the employment of anthropologists in their various research and development programs. The Government is not only sponsoring anthropological research but also giving emphasis on the teaching of anthropology at different levels of education. In last $2 / 3$ years, a number of anthropology courses have been included in the curriculum of primary, secondary and higher secondary level of education.

Professional anthropologists are now working with a number of government-funded research projects implemented by the Ministry of Education and facilitated by the International Mother Language Institute, University Grants Commission, Bangladesh Bureau of Educational Information and Statistics (BANBEIS), and by the Prime Minister's Office through A2i (Access to Information) and Development Assistance for Minor Ethnic Communities (DAMEC) projects. Other Ministries of the Government have also some projects where anthropologists are working. Knowing the importance of anthropology in development, many of the international organizations working in Bangladesh such as the World Bank, UNDP, UNFPA, ILO, ICCDR'B, Action Aid, OXFAM, CARE Bangladesh, UNICEF, UNESCO, WFP and others are now increasingly looking for more anthropologists for their qualitative research and development programs (see Figure 3). 


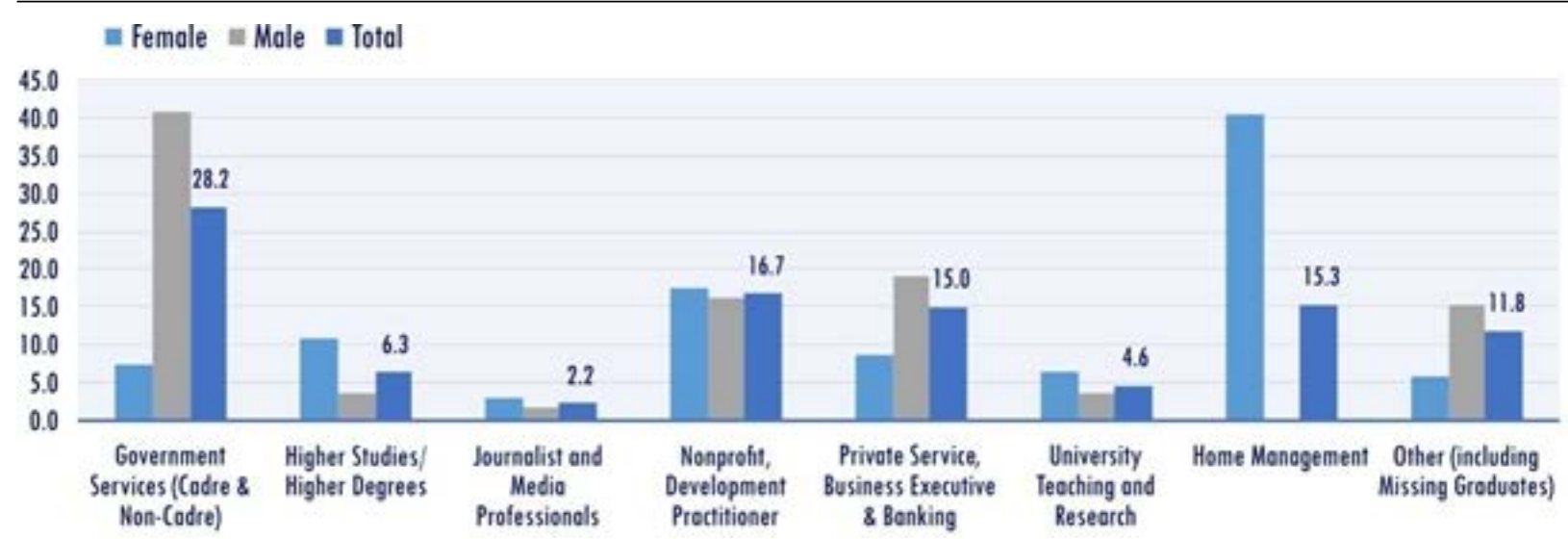

Figure 4. Major employment sectors of Anthropology graduates from 2005 to 2013

A statistical attempt has been made in Figure 4 in order to show the employment status of the anthropology graduates of the University of Dhaka. It demonstrates that Government services of various sorts stand for the highest sector of interest for the graduates. It does not take great effort to assume that in a developing country like Bangladesh job security is given highest priority. And it is equally a well-known fact that government jobs come with more security and even in bad situation like economic recession, government seldom opts for job cut. So, irrespective of any particular stream or profession, job seekers in Bangladesh prefer to be hired in government sectors. Figure 4 shows that $28.2 \%$ anthropology graduates have hitherto been appointed in various government jobs of which male students constitute $40 \%$ and that of the female students is $7.5 \%$. Development sector and private services respectively stand next to the government sectors in terms of priority given by the graduates. $16.7 \%$ graduates are involved in development organizations while 15\% opted for private services. The female to male ratio in government sector job participation rate shows that despite many attempts to ensure equal gender participation in every walk of life, female graduates are yet to find an equal footing in government sector jobs. If we consider that national scenario in this regard we would find that the ratio found among the anthropology graduates is of no exception. The Labour Force Survey conducted in $2012^{1}$ reveals that in 2010 while male participation in formal sectors stood for $14.5 \%$ that of the female was only $07.7 \%$. But it is a matter of hope that Bangladesh government, with an aim to achieve the SDG goals, has given highest priority to ensure increased female labour force participation. And it is presumable that female anthropology graduates won't fall behind to grasp the opportunities in the days to come. Hopeful scenario in terms of equal gender participation is already prevailing in non-governmental job sectors. But again, it is matter of despair that a great number of female graduates are involved in home management only which eventually echoes the dominant stereotypical image of womanhood and also contrasts the very spirit of anthropology.

\section{STREAMING ANTHROPOLOGY INTO NATIONAL DEVELOPMENT}

The anthropological engagement in and on development and the interface of applied anthropology and development has now become an important issue for discussion and debate. Engaging anthropology for development and social change also raises methodological, epistemological and ethical questions. A core concern of anthropology remains the engagement that fieldwork implies and such empirically grounded fieldwork provides anthropology with its ethnographic insights and analytical tools for understanding the society and its dynamics. Over the years, anthropologists have come to turn their attention to development as a critical anthropological subject of study. Yet the relationship between anthropology and development remains utterly ambiguous and contested. Consultancy and short-term research on a predefined problem have increased with the demand of development institutions for anthropological knowledge, a situation which seems to have deepened the schism between a theoretically oriented anthropology and a more applied anthropology. The major challenges of engaging anthropology are therefore to reconnect theory and practical application, and to create a platform for dialogue between a theoretically oriented, empirically grounded anthropology, and an anthropology directly applied to development and social change. It is fact that by the skillful and systematic combination of participation and observation of social life and social interaction, anthropologist is embedded in, and influences life in the social setting s/he is studying (Hagberg \& Ouattara, 2012; Sluka \& Robben, 2007). Same line of reasoning is suggested by Laurent, "Engagement is an obligation, and that non-engagement is a methodological error, because scientific validation in anthropology is done through the engagement to objectify one's subjectivity in order to establish the

\footnotetext{
${ }^{1}$ Bangladesh Bureau of Statistics (BBS) 2010. Gender Statistics of Bangladesh 2012. Statistics and Informatics Division Ministry of Planning Government of the People's Republic of Bangladesh. P. 70
} 
facts of reality, according to one's interlocutors" (Laurent, 2011).Nowadays, we can see that anthropological knowledge and perspectives are demanded by development agencies as it is considered badly needed to understand and, by extension, influence development and social change. But the main challenge for today's anthropology is how and by what means anthropology may engage in development in very practical ways with scientific rigor and methodological requirements. In terms of practicing anthropology, Low and Merry distinguish a number of forms of engagement: (1) sharing and support, (2) teaching and public education, (3) social critique, (4) collaboration, (5) advocacy, and (6) activism (Low \& Merry, 2010).

The situation of the development industry in Bangladesh is of no exception than that of the entire world and, might be said that, "It forces us to question some of our most deeply-held convictions and even to compromise between the interests of the communities we represent and those of donor agencies, who use the development discourse to achieve and maintain a position of power" (O'Driscoll, 2009). According to Pieterse, the development industry implicates 'an ideological performance in which discourse production, paradigm maintenance and tweaking the perception of receding horizons are the actual achievement'(Nederveen Pieterse, 2012; Pieterse, 2009). In Bangladesh, the value of social science, let alone anthropology, in development researches and activities was not even recognized until the late 1980s by GOs and NGOs. There is a disjunction between development projects and anthropologists, as Mannan suggests that development practitioners demand instant solutions, based on statistical figures, to their problems which anthropologists, very often, are unable to produce due to their disciplinary orientation(Mannan, 2006).

Does it mean that the avoidance of anthropological perspectives is coming with a better result for the project personnel? The answer is more often negative. In most cases what has been observed is the fact that project personnel, by seeking short-term solutions to their problem, are creating, though unintentionally, long-term problems which eventually initiates another new project and thus takes the development imperatives away from one of its central goal known as 'cost minimization'. A few cases from Bangladesh will help find how short-term problem solving attitude along with the exclusion of social science perspectives has created failures in the long term.

Bangladesh is a country of cultural and social diversity. A variety of occupational groups and communities live in Bangladesh covering a much diversified area of uplands, coasts, floodplains, hills and haor basins. Life and livelihood of communities in Bangladesh are very much dependent on different ecosystems and their services. People and the communities living and working in different regions and environments, in rural or urban areas, in coastal or hill areas, have different social and cultural backgrounds, livelihood practices and economic activities. To address any problem of these diversified communities, development policy and planning should be taken with proper understanding about the communities and programs for such communities should reflect the aspirations of the communities (Saifur \& Islam, 1997).

Since independence, Bangladesh has been undergoing with many large scheme development programs implemented by both the government and non-government local and international agencies. Many of such big projects, for example Jamuna Multipurpose Bridge Project (JMBP), Flood Action Plan (FAP), Dhaka Metropolitan Development Plan (DMDP), Dhaka-Narayanganj-Demra (DND) embankment project, Beel Dakatia Project (Khulna and Jessore District), Chandpur Scheme, Meghna-Dhonagada Irrigation Project had become less effective and created a lot of social, economic and environmental problems, as these were not developed in consultation with the grassroots people and were not implemented through the participation of local stakeholders (Saifur \& Ahmed, 2001; Saifur \& Islam, 1997; Saifur \& Mahmood, 2016). For many instances, policies were formulated by the administrators and the development professionals through conventional top-down approach. A closer look at the FAP example reveals that FAP not only ignored the people's participation but also adopted anti-people activities such as embankment construction and land acquisition which ultimately worked as 'death trap' for many of the local people. Without considering the people's knowledge base, FAP rather took some inappropriate programs and created conflicts among the local communities. The ongoing Padma Multi-Purpose Project and the Rampal Coal Based Power Generation Project might have the same fate, if these projects are not implemented on the basis of the consultation with its various stakeholders in collaboration with the people like anthropologists and other social scientists who are capable to work with the people at the project level and can understand the immediate and long term impacts of any of these projects on the local community, economy and the environment. However, the broader national policy making, planning and programme design process completely follow a topdown approach without any proper accounting of local peoples' perspectives or community voice.

It is now a fact that for determining an appropriate development intervention, planners should have sufficient knowledge about the community or the stakeholders. It is also required to understand that stakeholders know a great deal not only about their circumstances, resource status, needs and constraints but also capable to take new scheme for their own development in their own ways even with their limited resources. The more the government and other development agencies engage anthropologists in their policy formulation and intervention process, it is expected that the program will be more sustainable, equitable and effective. The situation demands an 
anthropological approach in the public policy making in Bangladesh because 'anthropological approach uncovers the constellations of actors, activities, and influences that shape policy decisions, their implementation, and their results' (Wedel, Shore, Feldman, \& Lathrop, 2005).

\section{TOWARD A MORE ENGAGED ANTHROPOLOGY IN BANGLADESH}

In this article, we endeavor to provide an overview of anthropology's history and the future prospects for the discipline in Bangladesh. Although the preceding discussion focused on the shared legacy of anthropology in India and Bangladesh, yet there are differences in these two national traditions. Reflections on anthropology, as a field of scholarship and research practices in India, it might be said that the discipline has somewhat been subsumed within sociology owing, perhaps, to its intellectual heritage in British Social Anthropology. In many Indian Universities, sociology-anthropology department is combined under the label of 'sociology' without differentiating between anthropology and sociology. This type of disciplinary configuration is also validated by eminent Indian scholar, Professor M. N. Srinivas, a British trained social anthropologist, who rejected the label 'anthropology' in favor of sociology (Thompson, 2012)cf.(Chatterji, 2005): 163). Absorbing anthropology within sociology represents, according to Thompson, "a particular British post-colonial position that sought to suppress the very colonial conditions of anthropology, especially British anthropology, which would come under such harsh criticism in the following decades" (ibid: 669). However, unlike Indian context, we observe a strong tradition of divergence between anthropology and sociology in Bangladesh. The public universities in Bangladesh house both anthropology and sociology as separate departments and recruit faculty members and new students separately. These departments have played a significant role in giving anthropology a public profile and as a focal point for interactions among members of anthropologists' community over the past decades in the country.

The public visibility of anthropology in Bangladesh, as a discipline, has somewhat increased in recent years. A close examination of the contemporary anthropological practice, in the country, suggests the priorities of bringing public engagement close to the center of the discipline. The call for an engaged anthropology that addresses public issues has received growing importance is many recent articles and books (Basch, Saunders, Sharff, \& Peacock, 1999; Borofsky, 2000, 2010; Lamphere, 2004; Low \& Merry, 2010; Patterson, 2001; Rylko-Bauer, Singer, \& Willigen, 2006). Anthropology needs to find approaches and ways to generate the impacts of the discipline and connect to wider audiences (Borofsky, 2010; Rylko-Bauer et al., 2006). As Peacock suggests, "If the discipline is to gain recognition and a valuable identity, it must accomplish things; it must be active beyond its analytical strategy. Pragmatism and searching critique need not be mutually exclusive" (Peacock, 1997):12). Following from this line, anthropology in Bangladesh should respond to this call for more engaged anthropology and generate significant impact on both academia and the broader social arena, thereby contributing to widen the horizon of anthropological work in Bangladesh. In a conference at Dhaka in 2005, while discussing on the prospects and future directions of anthropology in Bangladesh, Professor Fredrik Barth expressed that, "I think ... you have a marvelous opportunity with the kind of enthusiasm that I see among you, and you can make some very good anthropology"(Islam \& Shafie, 2006).

\section{REFERENCES}

Adnan, S. and Rahman, H.Z. (1978). Peasant Classes and Land Mobility: Structural Reproduction and Change in Rural Bangladesh. Bangladesh Historical Studies, 3, pp. 161-215.

Ahmad, N. (1956). The pattern of rural settlement in East Pakistan. Geographical review, 46(3), pp. 388-398.

Ahmed, N.U. (1969). The peasant family and social status in East Pakistan. University of Edinburgh.

Ali, Q.A. (1975). Rural development in Bangladesh. Bangladesh Academy for Rural Development.

Ambedkar, B. (1945). What Congress and Gandhi have done to the Untouchables. Gautambookcentre.

Arefeen, H.K. (1986). Changing Agrarian Structure in Bangladesh: Shimulia, a Study of a Periurban Village. Centre for Social Studies.

Arens, J. and Van Beurden, J. (1980). Jhagrapur; poor peasants and women in a village in Bangladesh.

Aurousseau, M. (1920). The Arrangement of Rural Populations. Geographical review, 10(4), pp. 223-240.

Aziz, K. (1979). Kinship in Bangladesh.

Aziz, K. and Maloney, C. (1985). Life stages gender and fertility in Bangladesh.

Baden-Powell, B.H. (1896). The Indian Village Community: Examined with Reference to the Physical, Ethnographic and Historical Conditions of the Provinces; Chiefly on the Basis of the Revenue-settlement Records and District Manuals. Longmans, Green, and Company.

Bailey, F.G. (1957). Caste and the economic frontier: A village in highland Orissa. Manchester University Press.

Bailey, F.G. (1970). Politics and social change: Orissa in 1959. Univ of California Press. 
Basch, L.G., Saunders, L.W., Sharff, J.W. and Peacock, J. (1999). Transforming academia: challenges and opportunities for an engaged anthropology: American Anthropological Assoc.

Battuta, I. (2004). Travels in Asia and Africa: 1325-1354. Routledge.

Beech, M.J., Bertocci, P.J., Corwin, L.A., ... Schuler, E.A. (1966). Introducing the East Bengali Village. In Inside the East Pakistan Village - Six Articles, Michigan State University.

Bernier, F. (1916). Travels in the Mogul Empire, AD 1656-1668. Archibald Constable.

Bernot, D. (1958). Rapports phonétiques entre le dialecte marma et le birman. Librairie C. Klincksieck.

Bernot, L. (1960). Ethnic groups of Chittagong Hill tracts. Asiatic Society of Pakistan.

Bertocci, P.J. (1972). Community structure and social rank in two villages in Bangladesh. Contributions to Indian sociology, 6(1), 28-52.

Bertocci, P.J. (1977). Elusive villages: social structure and community organization in rural East Pakistan. PhD Dissertation, Michigan State University, Department of Anthropology.

Bertocci, P.J. (1984). Bengalis. In R.V. Weekes, eds. Muslim Peoples: A World Ethnographic Survey, Westport, CT: Greenwood Press, pp. 137-141.

Bessaignet, P. (1958). Tribesmen of the Chittagong Hill Tracts. Asiatic Society of Pakistan.

Beteille, A. (1965). Caste, class, and power. Changing patterns of stratification in a Tanjore village: Univ of California Press.

Blair, H.W. (1974). The Elusiveness of Equity: Institutional Approaches to Rural Development in Bangladesh. Rural Development Committee, Center for International Studies, Cornell University.

Blanchet, T. (1984). Meanings and rituals of birth in rural Bangladesh. Women pollution and marginality.

Bontekoe, W.Y. (1929). Memorable Description of the East Indian Voyage: 1618-1625 (P. Geyl, Trans.). London: Routledge.

Borofsky, R. (2000). Commentary: Public Anthropology. Where To? What Next? Anthropology News, 41(5), pp. 910.

Borofsky, R. (2010). Why a Public Anthropology? : Center for a Public Anthropology, Hawaii Pacific University.

Bose, N.K. (1929). Cultural Anthropology: And Other Essays. [Reprinted with Additions]. Indian Associated Publishing Company, Limited.

Bose, N.K. (1967). Peasant life in India: a study in Indian unity \& diversity (Vol. 8). Anthropological Survey of India.

Bouchon, G. and Thomaz, L.F. (1988 [Original in 1521]). Voyage dans les deltas du Gange et de l'Irraouaddy. Paris: Centre Culturel Portugais.

Brown, A.R.R. (1922). The Andaman Islanders (Vol. 92558). London: Free Pr.

Buchanan, F. (1799). A comparative vocabulary of some of the languages spoken in the Burma Empire. Asiatick Researches or Transactions of the Society instituted in Bengal for inquiring into the History and Antiquities, the Arts, Sciences and Literature of Asia, 5, pp. 219-240.

Buchanan, F. (1807). A Journey from Madras through the Countries of Mysore, Canara and Malabar. T. Cadell and W. Davies.

Campbell, G. (1874). Specimens of the Languages of India Including Those of the Aboriginal Tribes of Bengal: Calcutta: Bengal Government Press.

Chakroborty, R. (1977). Chakma resistance to early British rule. Bangladesh Historical Studies: Journal of the Bangladesh Itibaas Samiti, 2, pp. 133-156.

Chatterji, R. (2005). An Indian Anthropology? What Kind of Object is it. Asian Anthropology. London and New York: Routledge, pp. 162-176.

Chowdhury, A. (1978). A Bangladesh village: a study in social stratification: Centre for Social Studies Dhaka.

Chowdhury, R.I., Mia, M.R., Hossain, M., Choudhury, A. and Golamquddus, A. (1979). Tribal Leadership and Political Integration: A Case Study of Chakma and Mong Tribes of Chittagong Hill Tracts. Faculty of Social Science, University of Chittagong, Bangladesh, July, Memo. p. XX, 248.

Dalton, E.T. (1872). Descriptive ethnology of Bengal. Office of the Superintendent of government printing.

Datta-Majumder, N. (1956). The Santal: A study in culture-change. Manager of publications.

Du Jarric, F.P. (1615). Histoire des choses plus memorables advenues tant ez. Indes Orientales, que autres païs de la descouverte des Portugais, en l'establissment... de la foy Chrestienne... par le P. Pierre Du Jarric. par S. Millanges.

Dube, S. (1963). Men's and women's roles in India: A sociological review. Women in the new Asia.

Dube, S.C. (1958). India's changing villages: human factors in community development. India's changing villages: buman factors in community development.

Dube, S.C. (1964). Bureaucracy and nation building in transitional societies. UNESCO.

Dumont, L. (1969). Homo hierarchicus. Paris, Éditions Tell.

Dumont, L. and Pocock, D.F. (1957). Village studies. Contributions to Indian sociology, 1(23-41).

Ellickson, J. (1972). A believer among believers: the religious beliefs, practices, and meanings in a village in Bangladesh. Michigan State University. 
Elwin, V. (1947). The Muria and their ghotul.

Elwin, V. (1964). The tribal world of Verrier Elwin: an autobiography. Oxford University Press New York/Bombay.

Eriksen, T.H. and Nielsen, F.S. (2001). A bistory of anthropology.

Furer-Haimendorf, E.V. (1958). An Anthropological Bibliography of South Asia. Mouton and Co, Paris.

Gait, E.A. (1906). A bistory of Assam. Thacker, Spink \& Company.

Ghurye, G.S. (1957). Caste and class in India. Popular Book Depot.

Ghurye, G.S. (1969). Caste and race in India. Popular Prakashan.

Gough, E.K. (1955). The social structure of a Tanjore village. Village India, 40, 1955.

Greenhill, B. and HILL, C. (1957). The Boats of East Pakistan a Preliminary Study. The Mariner's Mirror, 43(2), 106134.

Grierson, G. (1904). Linguistic Survey of India Vol III Part III.

Grierson, G.A. (1906). Linguistic survey of India (Vol. 4). Office of the superintendent of government printing, India.

Grierson, G.A. (1968). Linguistic survey of India. 5: Indo-aryan family, eastern group; 2. Motilal Banarsidass.

Guha, B.S. (1936). The racial affinities of the people of India. Imprimerie médicale et scientifique.

Hagberg, S. and Ouattara, F. (2012). Engaging anthropology for development and social change. Bulletin de l'APAD (34-36).

Haq, M.N. (1973). Village Development in Bangladesh: A Study of Monagram Village. Bangladesh Academy for Rural Development.

Hara, T. (1967). Paribar and Kinship in a Moslem Rural Village in East Pakistan.

Hartmann, B. and Boyce, J. K. (1983). A quiet violence: view from a Bangladesh village. Zed Books.

Hasan, K.A. (1967). The Cultural Frontier of Health in Village India: Case Study of a North Indian Village. Manaktalas.

Havell, E.B. (1918). The History of Aryan Rule in India: From the Earliest Times to the Death of Akbar. KMN Publishers; [distributors: Atma Ram, Delhi.

Herbon, D. (1985). The system of exchange and distribution in a village in Bangladesh. Herodot.

Hodson, T. (1921). The Garo and Khasi marriage systems contrasted. Man in India, 1(2), 18-39.

Hodson, T.C. (1922). The Primitive Culture of India: Lectures. Royal Asiatic Society.

Hoernle, A.F.R. and Stark, H.A. (1906). A History of India. Orissa Mission Press.

Hosten, F.H. (1925). Jesuit letters from Bengal, Arakan and Burma (1599-1600). Bengal Past and Present, 30, $52-76$.

Huan, M. and Ch'eng-Chün, F. (1970 [Original in 1544]). Ying-yai Sheng-lan: The Overall Survey of the Ocean's Shores (1433). Trans. and ed. JVG Mills. London: The Hakluyt Society.

Hughes, W.G. (1881). The Hill Tracts of Arakan. Printed at the Government Press.

Hunter, W. (1876). A Statistical Account of Bengal. Volume VI, Chittagong Hill Tracts, Chittagong, Noakhali, Tipperah, Hill Tipperah. London. Trubner Co.

Hunter, W.W. (1886). The Indian Empire: Its Peoples, History, and Products. Trübner \& Company.

Hunter, W.W., Kisch, H.M., Mackie, A.W., O’Donnell, C.J. and Risley, H.H. (1877). A statistical account of Bengal (Vol. 20). Trübner \& Company.

Husain, S.S. (1962). East Pakistan: A Profile. Orient Longmans.

Hutchinson, R.H.S. (1906). An Account of the Chittagong Hill Tracts. Bengal Secretariat Book Depot.

Hutchinson, R.S. (1909). Eastern Bengal and Assam District Gazetteers: Chittagong Hill Tracts. Pioneer press Allahabad.

Hutton, J. (1921). The Angari Nagas. London: MacMillan and Company.

Hutton, J.H. (1946). Caste in India: Its nature, function and origins.

Hutton, J.H. (1961). Caste in India. Oxford University Press.

Islam, A. (1969). Conflict and Cohesion in an East Pakistan Village. Ph. D. Dissertation. Montreal: McGill University.

Islam, A. (1973). Bangladesh in Transition: Reformation and Accommodation. Southasian Series Occasional Paper (21).

Islam, A.A. (1974). A Bangladesh Village: Conflict and Cohesion: An Anthropological Study of Politics. Schenkman Publishing Company.

Islam, S. and Ray, N. (1984). Tribal Resistance in the Chittagong Hill Tracts (1776-1787). Saga of Freedom (Delbi: People's Publishing, 1983), 122-129.

Islam, S.N. (1981). The Chittagong Hill tracts in Bangladesh: Integrational crisis between center and periphery. Asian Survey, 21(12), 1211-1222.

Islam, Z. and Shafie, H. (2006). Anthropology on the Move: Contextualizing Culture Studies in Bangladesh. Department of Anthropology, University of Dhaka.

Jack, J. (1915). Final Report on the Survey and Settlement Operations in the Bakarganj District, 1900 to 1908. Bengal Secretariat Book Depot.

Jahangir, B.K. (1979). Differentiation, polarisation and confrontation in rural Bangladesh/BK Jahangir.

Jannuzi, F., Jannuzi, J.T.T. and Peach, J.T. (1980). The agrarian structure of Bangladesh: an impediment to development.

Jansen, E.G. (1987). Rural Bangladesh: Competition for scarce resources. University Press Dhaka. 
Jones, S.W. (1784). A discourse on the institution of a society for enquiring into the history, civil and natural, the antiquities, arts, sciences, and literature of Asia, delivered at Calcutta, January 15th, 1784 [electronic resource]: A charge to the Grand Jury at Calcutta, December 4th, 1783: and a hymn to Camdeo, translated from the Hindu into Persian, and from the Persian into English. By Sir William Jones. T. Payne and So, at the Mews Cate, Castle Street, St. Martin's; and sold at the Pamphlet Shops.

Jones, W. (1801). The Works of Sir William Jones. Robinson.

Karim, A. (1984). Rural Elites and Their Role in Conflict Resolution: Three Arenas and Some Cases. Bangladesh Journal of Sociology, 2(2).

Karim, A.K.N. (1976). Changing Society in India, Pakistan and Bangladesh. Nawroze Kitabistan.

Karim, A.N. (1974). Social Sciences in Bangladesh Paper presented at the Symposium on Social Science Research Development in Asia, Jakarta, Indonesia.

Karim, A.Z. (1990). The Pattern of Rural leadership in an Agrarian Society: A Case Study of the Changing Power Structure in Bangladesh. Northern Book Centre.

Kauffmann, H.E. (1962). Observations on the agriculture of the Chittagong hill-tribes. Asiatic Soc. of Pakistan.

Khan, F. and Choudhuri, S.I. (1965). Some tribal house types of the Chittagong Hill Tracts. The Oriental Geographer, 9(1), 17-32.

Khan, F.K. and Khisha, A.L. (1970). Shifting cultivation in East Pakistan. Oriental Geographer (July), 22-43.

Khan, F.R. (1979). District Town Elites in Bangladesh. Asian Survey, 19(5), 468-484.

Konow, S. (1903). Notes on the Maghī dialect of the Chittagong Hill Tracts. Zeitschrift der Deutschen Morgenländischen Gesellschaft, 57(1), 1-12.

Lamphere, L. (2004). The convergence of applied, practicing, and public anthropology in the 21st century. Human Organization, 63(4), 431-443.

Laurent, P. (2011). Observation participante et engagement en anthropologie. Investigations d'anthropologie prospective: implications et explorations éthiques en anthropologie (eds) J. Hermesse, M. Singleton \& A.-M. Vuillemenot. Lowvain-la-Newve. Harmattan_Academia.

Leach, E.R. (1960). Aspects of caste in south India, Ceylon and North-west Pakistan. CUP Archive.

Legge, J. (1886). A Record of Duddhistic Kingdoms being an Account by the Cbinese Monk Fa-Hien His Travels in India and Ceylon (AD 399-414) In Search of the Buddhist Books of Discipline Translated and Annotated with a Corean Recension of the Chinese Text.

Levi-Strauss, C. (1951). 284. Miscellaneous Notes on the Kuki of the Chittagong Hill Tracts, Pakistan. Man, 51, 167-169.

Lévi-Strauss, C. (1952). Kinship systems of three Chittagong hill tribes (Pakistan). Southwestern Journal of Anthropology, 40-51.

Lewin, T.H. (1869). The Hill Tracts of Chittagong and the dwellers therein; with comparative vocabulary. Calcutta.

Lewin, T.H. (1870). Wild races of South-eastern India. WH Allen \& Company.

Lewin, T.H. (1885). A Fly on the Wheel; Or, How I Helped to Govern India. Constable Limited.

Lewis, O. (1958). Village life in northern India.

Lindenbaum, S. (1968). Woman and the left hand: social status and symbolism in East Pakistan. The Australian Journal of Anthropology, 6(11), 537.

Löffler, L.G. (1964). Chakma und Sak: ethnolinguistische Beiträge zur Geschichte eines Kulturvolkes. SAI.

Löffler, L.G. (1968). Basic Democracies in den Chittagong Hill Tracts, Ostpakistan. Sociologus, 152-171.

Low, S.M. and Merry, S.E. (2010). Engaged anthropology: diversity and dilemmas. Current anthropology, 51(S2), S203S226.

Mackenzie, A. (1884). History of the relations of the government with the Hill Tribes of the North East Frontier of Bengal.

Majumdar, D.N. (1937). A tribe in transition: a study in culture pattern. Longmans, Green \& co., ltd.

Majumdar, D.N. (1947). The Matrix of Indian Culture. Nagpur University.

Majumdar, D.N. (1958). Caste and communication in an Indian village/by DN Majumdar.

Majumdar, D.N. (1961). Races and cultures of India. Asia Pub. House.

Mannan, M. (2006). Cooperative Antagonism in Development Research: A Perspective From Bangladesh. Anthropology in Action, 13(3), 54-62.

Manrique, F.S., Trans. by Luard, C.E. and Hosten, H. (1926 [Original in 1653]). Itinerate Rio Dila Missionery Del India Oriental Trans. Travels of Fray Sébastien Marnrique. London: The Hakluyt Society.

Marriott, M. and Beals, A.R. (1955). Village India; studies in the little community.

Martius-von Harder, G. (1981). Women in Rural Bangladesh: an empirical study in four villages of Comilla district.

Mayer, A.C. (1956). Some hierarchical aspects of caste. Southwestern Journal of Anthropology, 117-144.

MAYER, A.C. (1960). Caste and kinship in Central India, a village and its region. Caste and kinship in Central India, a village and its region. 
McCarthy, F.E. (1967). Bengali village women: mediators between tradition and development. Michigan State Univ., Department of Sociology.

Mey, W. (1978). A preliminary report of socio-economic change among the ethnic groups and communities of the Chittagong hill tracts, Bangladesh. Aspects of Tribal Life in South Asia 1: Strategy and Survival, 201-208.

Miller, B.D. (1984). Daughter neglect, women's work, and marriage: Pakistan and Bangladesh compared. Medical anthropology, 8(2), 109-126.

Mills, J. (1931a). Notes on a Tour in the Chittagong Hill Tracts in 1926. Census of India, 5(Part 1).

Mills, J. (1931b). Notes on the People of the Chittagong Hill Tracts. Census of India, 1, 118-125.

Morris, C. (1888). The Aryan Race: Its Origins and Its Achievements. SC Griggs.

Mukherjee, R. (1948). Economic Structure of Rural Bengal: A Survey of Six Villages. American Sociological Review, 13(6), 660-672.

Nathan, M. (1936). Baharistan-i Ghaybi. A History of the Mughal Wars in Assam, Cooch Behar, Bengal, Bihar and Orissa during the Reigns of Jahangir and Shah Jahan by Mirza Nathan.

Nederveen Pieterse, J. (2012). Twenty-first century globalization: a new development era. Paper presented at the Forum for Development Studies.

O’Malley, L. (1908). Chittagong, Eastern Bengal District Gazetteer, Calcutta, 1908.* cité O’Malley: Chittagong.

O’Driscoll, E. (2009). Applying the 'Uncomfortable Science': the Role of Anthropology in Development. Special Postgraduate Issue, 16(1), 13-21.

Opler, M.E. and Singh, R.D. (1952). Two villages of eastern Uttar Pradesh (UP), India: An analysis of similarities and differences. American Anthropologist, 54(2), 179-190.

Patterson, T.C. (2001). A social history of anthropology in the United States. Berg Publishers.

Peacock, J.L. (1997). The future of anthropology. American Anthropologist, 99(1), 9-17.

Phayre, A.P. (1841). Account of Arakan.

Phillips, G. (1885). The Seaports of India and Ceylon: Described by Chinese Voyagers of the Fifteenth Century, Together with an Account of Chinese Navigation. Royal Asiatic Society.

Pieterse, J.N. (2009). 2 twenty-first century globalization, paradigm shifts in development. Doing Good or Doing Better, 27.

Pinnow, H.-J., Kuiper, F., Shafer, R., Greenberg, J., Shevelenko, A. and Emeneau, M. (1942). The Position of the Munda Languages within the Austroasiatic Language Family. Language, 18, 206.

Pogson, W.R. (1831). Captain Pogson's narrative during a tour to Chateegaon, 1831. Serampore press.

Prance, B. (1916). Final Report on the Survey and Settlement Operations in the Riparian Area of District Tippera, Conducted with the Faridpur District Settlement, 1909-15. Bengal Secretariat Book Depot.

Qadir, S. (1960). Village Dhanishwar: Three Generations of Man-made Adjustment in an East Pakistan Village. Academy for Village Development.

Qureshi, M.S. (1984). Tribal cultures in Bangladesh (Vol. 5). Institute of Bangladesh Studies, Rajshahi University.

Rahim, M.A. (1963). Social and cultural history of Bengal. Pakistan Historical Society.

Rahman, A. (1981). Rural Power Structure: A Study of the Local Level Leaders in Bangladesh. Papri Publishers.

Rashiduzzaman, M. (1968). Politics and administration in the local councils: a study of union and district councils in East Pakistan. Oxford University Press.

Risley, H.H. (1892). The tribes and castes of Bengal (Vol. 1). Printed at the Bengal secretariat Press.

Risley, H.H. (1908). The People of India. Thacker, Spink \& Company.

Roy, S.C. (1912). Mundas and their country.

Roy, S.C. (1915). The Oraons of Chota Nagpur. Ranchi, India: Man in India.

Roy, S.C. (1916). The Divine Myths of the Mundas.

Roy, S.C. (1928). Oraon religion and customs.

Roy, S.N. (1916). The Conversion of Santals to Hinduism.

Rylko - Bauer, B., Singer, M. and Willigen, J. v. (2006). Reclaiming applied anthropology: Its past, present, and future. American Anthropologist, 108(1), 178-190.

Saifur, R. and Ahmed, S. (2001). Indigenous Knowledge, Beliefs and Practices of Fishermen: An Anthropological Observation. Grassroots Voice: A Journal of Indigenous Knowledge and Development, 11(04), 135-142.

Saifur, R. and Islam, Z. (1997). Essence of Peoples Participation and Indigenous knowledge in-Development. Social science Review, 14(01).

Saifur, R. and Mahmood, R. (2016). Anthropology's Engagement in Development: Some Conceptual and Contextual Issues. Social Science Review, The Dhaka University Studies, Part-D, Volume 33, Number 2, December 2016.

Sarkar, S.S. (1954). The aboriginal races of India.

Sarker, P.C. (1976). Aspects of Caste and Social structure in a Rural Community of Bangladesh. Unpublished M. Phil. Thesis, Rajshabi, Institute of Bangladesh Studies, Rajshahi University. 
Sattar, A. (1971). In the sylvan shadows/by Abdus Sattar.

Sattar, A. (1975). Tribal Culture in Bangladesh. Muktadhara.

Sebeok, T.A. (1942). An examination of the Austroasiatic language family. Language, 206-217.

Sen, M. (1931). Notes on the Maghs of Cox's Bazar. Census of India, 1(part 1), 121-125.

Serajuddin, A. (1971). The Origin of the Rajas of the Chittagong Hill Tracts and their Relations with the Mughuls and the East India Company in the Eighteenth Century. Journal of the Pakistan historical Society, 19(1), 51.

Serajuddin, A.M. (1984). The Chakma tribe of the Chittagong hill tracts in the 18th century. Journal of the Royal Asiatic Society of Great Britain \& Ireland (New Series), 116(01), 90-98.

Shafer, R. (1955). Classification of the Sino-Tibetan languages. Word, 11(1), 94-111.

Sherring, M.A. (1879). Hindu tribes and castes (Vol. 2). Thacker, Spink \& Company.

Sivertsen, D. (1963). When caste barriers fall. A Study of Social and Economic Change in a South Indian Village, Oslo.

Sluka, J.A. and Robben, A.C. (2007). Ethnographic fieldwork: An anthropological reader. London: Blackwell.

Smith-Forbes, C.J.F. (1881). Comparative grammar of the languages of Further India: a fragment and other essays. WH Allen \& Company.

Sopher, D.E. (1964). The Swidden/Wet-Rice Transition Zone in the Chittagong Hills. Annals of the Association of American Geographers, 54(1), 107-126.

Srinivas, M. and Shah, A. (1960). The myth of self-sufficiency of the Indian village. Economic Weekly, 12(37), 13751378.

Srinivas, M.N. (1952). Religion and society among the Coorgs of South India.

Srinivas, M.N. (1960a). India's villages. India's villages.

Srinivas, M.N. (1960b). The social structure of a Mysore village. Bobbs-Merrill.

St-John, R. (1873). A Short Account of the Hill Tribes of North Arakan. Journal of Anthropological Institute of Great Britain and Ireland, 2, 233-247.

Thompson, E.C. (2012). Anthropology in Southeast Asia: National Traditions and Transnational Practices. Asian Journal of Social Science, 40(5-6), 664-689.

Thorner, D. (1966). Marx on India and the Asiatic mode of production. Contributions to Indian sociology, 9(1), 3-66.

Thorp, J.P. (1978). Power among the farmers of Daripalla. A Bangladesh village study: Caritas Bangladesh.

Van der Heiden, F.J. (1675). Vervarelyke Schip-breuk van 'T Oost-Indisch Jacht Ter Schelling Amsterdam. Boekverkoper.

Van Schendel, W. (1981). Peasant mobility: the odds of life in rural Bangladesh.

Vidyarthi, L.P. (1969). Socio-cultural Implications of Industrialisation in India: A Case Study of Tribal Bibar. Delite Press.

Von Hevesy, W. (1930). On Wilhelm Schmidt's Munda-Mon-Khmer comparisons (Does an "Austric" family of languages exist?). Bulletin of the School of Oriental Studies, 6(1), 187-200.

Wedel, J.R., Shore, C., Feldman, G. and Lathrop, S. (2005). Toward an anthropology of public policy. The ANNALS of the American Academy of Political and Social Science, 600(1), 30-51.

Westergaard, K. (1983). Pauperization and Rural women in Bangladesh.

Whitney, W.D. (1875). Indo-European language.

Wiser, W.H. (1936). The Hindu jajmani system: a socio-economic system interrelating members of a Hindu village community in services/by William Henricks Wiser.

Wood, G.D. (1976). Class differentiation and power in Bandakgram: The minifundist case. Exploitation and the Rural Poor, Comilla: Bangladesh Academy for Rural Development.

Xuanzang, \& Beal (Trans.), S. (1958). Chinese accounts of India. Susil Gupta.

Zaidi, S.M.H. (1970). The village culture in transition. A study of East Pakistan rural society. The village culture in transition. A study of East Pakistan rural society.

Zaman, M. (1982). Corporate groupings, religious ideology and community leadership in a village of Bangladesh. South Asian Anthropology, 3(2), 39-45. 